\title{
Sedimentary photosynthetic pigments as indicators of climate and watershed perturbations in an alpine lake in southern Spain
}

\author{
Laura Jiménez ${ }^{1,2, *}$, Lidia Romero-Viana, José María Conde-Porcuna ${ }^{1,2}$, and Carmen Pérez- \\ Martínez ${ }^{1,2}$ \\ ${ }^{1}$ Institute of Water Research, University of Granada, 18071-Granada, Spain. \\ 2 Department of Ecology, Faculty of Science, University of Granada, 18071 Granada, Spain. \\ * Corresponding author: laurajl@ugr.es
}

Received: 23/02/2015 Accepted: 14/07/2015

\begin{abstract}
Sedimentary photosynthetic pigments as indicators of climate and watershed perturbations in an alpine lake in southern Spain

A short core was collected in Río Seco Lake, an alpine and oligotrophic lake located in the Sierra Nevada Mountains (in the southeast region of Spain) to determine the algal group changes over the past 200 years. In particular, it was analysed for fossil pigments and their derivatives and the geochemical ( $\mathrm{C} / \mathrm{N}$ ratio, grain-size analyses and isotopic dating) and climatic (temperature and rainfall values obtained from a long instrumental series) variables. The main pigments were carotenoids that indicate cyanobacteria (zeaxanthin, echinenone and myxoxanthophyll), diatoms and chrysophytes (fucoxanthin and diadinoxanthin) and green algae (lutein). The changes in pigment abundance over time were mainly explained by the temperature. Zeaxanthin showed a marked decrease from the $19^{\text {th }}$ century to the present and is attributed to picoplanktonic cyanobacteria in Río Seco Lake. This decrease may result from climate-driven factors affecting herbivorous grazing pressure and water residence time. The increasing human activity around the lake likely generated a high input of carotenoid-poor pigmented organic matter and led to the dilution of chlorophylls and labile carotenoids observed over recent decades.
\end{abstract}

Key words: Paleolimnology, sedimentary pigments, HPLC, alpine lake, Sierra Nevada.

\section{RESUMEN}

Pigmentos fotosintéticos sedimentarios como indicadores de perturbaciones climáticas y de la cuenca en un lago alpino del sudeste de España

Se tomó un testigo corto de sedimento de la laguna de Río Seco, un lago alpino y oligotrófico localizado en Sierra Nevada (sudeste de España) para determinar los cambios en la comunidad algal de los últimos 200 años. Se analizaron pigmentos fósiles y sus derivados, variables geoquímicas (índice $C / N$, análisis granulométrico e isótopos de datación) y variables climáticas (valores de temperatura y precipitación procedentes de series instrumentales extensas). Los principales pigmentos analizados fueron carotenoides indicadores de cianobacterias (zeaxantina, equinona y mixoxantofila), diatomeas y crisoficeas (fucoxantina y diadinoxantina) y algas verdes (luteína). Los cambios en la abundancia de pigmentos se explicaron principalmente por la temperatura. La zeaxantina presentó un marcado descenso desde el siglo XIX hasta la actualidad, y se atribuye a las cianobacterias picoplanctónicas en la laguna de Río Seco. Este descenso puede producirse por factores dependientes del clima que afectan a la presión de herbivoría y al tiempo de residencia del agua. La creciente actividad humana alrededor de la laguna probablemente generó un alto aporte de materia orgánica pobremente pigmentada, provocando una dilución de clorofilas y carotenoides lábiles en décadas recientes.

Palabras clave: Paleolimnología, pigmentos sedimentarios, HPLC, lago alpino, Sierra Nevada. 


\section{INTRODUCTION}

Remote lakes are considered excellent ecosystems to study the effects of climate and environmental changes (Sorvari \& Korhola, 1998; Smol, 2008) because they are above the treeline with no severe perturbations in their catchment area and are extremely sensitive to climatic warming (Hauer et al., 1997; Smol et al., 2005). The effects of recent warming are documented in the Arctic (Douglas et al., 1994; Smol et al., 2005; Rühland et al., 2013) and in high-mountain systems in the Alps and Pyrenees (SommarugaWögrath et al., 1997; Lotter et al., 1997; Catalan et al., 2002), Rocky Mountains (Hobbs et al., 2010; Hundey et al., 2014), Himalayas (Rühland et al., 2006) and Andes (Michelutti et al., 2015).

Among the numerous proxies employed in paleolimnological studies, sedimentary photosynthesis pigments can provide reliable records of changes in primary production and algal community composition in lakes (e.g., Romero-Viana et al., 2009, 2010) and modifications in their biotic and physical environment (e.g., Verleyen et al., 2005). Sedimentary pigment studies in remote lakes have revealed an increase in primary production as a result of climate warming (Battarbee et al., 2002; Michelutti et al., 2005; Lami et al., 2010), and an increase in cyanobacterial abundance was shown in many of the lakes in the MOLAR European project (Lami et al.,1998; Lami et al., 2000). These changes have been attributed to a lengthening of the ice-free period and growing season, a greater water column stability, and an increase in catchment nutrient fluxes and algal habitat availability. However, some authors have reported that pigment composition changes were small and independent of temperature (Koinig et al., 2002). It appears that the amount and direction of change may depend upon the site including the lake's limnologic characteristics and the geographical setting (Sommaruga-Wögrath $e t$ al., 1997; Corbett \& Munroe, 2010; Luoto \& Nevalainen, 2013). Furthermore, the climate signal may sometimes be obscured in the sediment record due to the impact of other factors, notably those related to direct human disturbance (Battarbee et al., 2002; Catalan et al., 2013).
These include: watershed and shoreline erosion caused by an increased number of visitors (Toro et al., 2006), long-distance air transport of pollutants and/or nutrients that produces acid deposition and eutrophication problems (Lotter \& Birks, 1997; Wolfe et al., 2001; Battarbee et al., 2009; Smol, 2010; Catalan et al., 2013), and fisheries management (Alric et al., 2013), among other human activities. Differentiating between limnological responses of lake ecosystems to human and climate-change stressors is a challenging task for paleolimnologists and limnologists (Smol, 2010) and may be facilitated by the utilization of a combination of paleolimnological proxies.

The Sierra Nevada mountain range is a unique environment for analysing phenomena directly related to global change. It is the southernmost mountain range in Europe and the highest on the Iberian Peninsula with elevations greater than $3000 \mathrm{~m}$ a.s.l. It is also situated between two biogeographic regions (Europe and Africa) and its longitudinal west-east shape creates watersheds with different influences. The Sierra Nevada is approximately $60 \mathrm{~km}$ from the coast and is governed by a semi-arid Mediterranean climate. These characteristics have led high-mountain lakes of the Sierra Nevada to be considered ideal reference sites for climate monitoring.

Limnological studies have previously described the influence of interannual climatic variations (temperature/rainfall and Saharan deposition) on the biogeochemical variables and biota in the lakes of the Sierra Nevada (Morales-Baquero et al., 2006a; Pérez-Martínez et al., 2007), but no data are available on the direct and indirect effects of climate change on century time scales. The present study was designed to determine the changes in sedimentary photosynthesis pigments in Río Seco Lake over the past 200 years.

Our research group has accumulated an abundance of information on the chemical and physical conditions of Río Seco Lake and is engaged in an intensive program to monitor planktonic communities and physicochemical variables. It is also possible to identify a specific period of human pressure on the catchment area that occurred be- 
tween the construction of a dirt road and a mountain hut close to the lake shoreline in the 1960 s and their destruction in the late 1990s. Vehicular access produced a major increase in the number of same-day and overnight visitors during this 30-year period. With this background knowledge, we hypothesized that the algal community in Río Seco Lake could be affected by recent warming and by direct catchment perturbations and that these changes are recorded in the lake sediment. The specific objectives of this study, using a sediment core from the Rio Seco Lake, were to estimate changes in the algal community over the past 200 years by analysing the pigment record and identifying signs of catchment perturbation by analysing geochemical variables. The aim was to determine the effects of global warming and those of human-induced catchment perturbation.

\section{MATERIALS AND METHODS}

\section{Site description}

Río Seco $\left(37^{\circ} 03^{\prime} \mathrm{N}, 3^{\circ} 20^{\prime} \mathrm{W}\right)$ is a small (0.4 ha surface and 9.9 ha catchment area), oligotrophic, and shallow $\left(Z_{\max }=2.90 \mathrm{~m}\right)$ lake of glacial origin located at $3020 \mathrm{~m}$ a.s.l. in the Sierra Nevada Mountains (southern Spain) above the tree-line (Fig. 1). The maximum depth was determined by a surface outflow. The lake is ice-covered from around October-November until June-July with a large interannual variability. Data have been published on the physicochemical characteristics of the lake in different years (Barea-Arco et al., 2001; Morales-Baquero et al., 2006a; PérezMartínez et al., 2013). During the ice-free period, Secchi disk visibility exceeds the water depth, the lake is not thermally stratified (see thermistor data in García-Jurado et al., 2011), and the maximum temperature is $16-18{ }^{\circ} \mathrm{C}$. Dissolved organic carbon values range from 62.1 to $283.5 \mathrm{mmol} / \mathrm{L}$, conductivity values from 9.84 to $16.29 \mu \mathrm{S} / \mathrm{cm}$, $\mathrm{pH}$ values from 6 to 7.4 and acid neutralizing capacity values from 0.05 to $0.20 \mathrm{meq} / \mathrm{L}$. It is a fishless lake, the chlorophyll concentration is approximately 0.5-2 $\mu \mathrm{g} / \mathrm{L}$ (Morales-Baquero et al., 2006a), and the phytoplankton biomass is less than $20 \mu \mathrm{gC} / \mathrm{L}$ (Peréz-Martínez et al., 2012). The lake bedrock basin is siliceous and largely comprised of micaschists. The catchment area is partially covered $(\sim 15 \%)$ by alpine meadows, and the lake border is covered by bryophytes.

\section{Sediment coring and sampling}

A sediment core was collected from the deepest part of the lake in September 2008 using a slidehammer gravity corer (Aquatic Research Instruments, Hope, Idaho, USA) with an inner diameter of $6.8 \mathrm{~cm}$. The core $(16 \mathrm{~cm})$, which was extracted in a methacrylate cylinder, was immediately wrapped in a dark bag to keep it protected from the light, sectioned into $0.5 \mathrm{~cm}$ slices, and

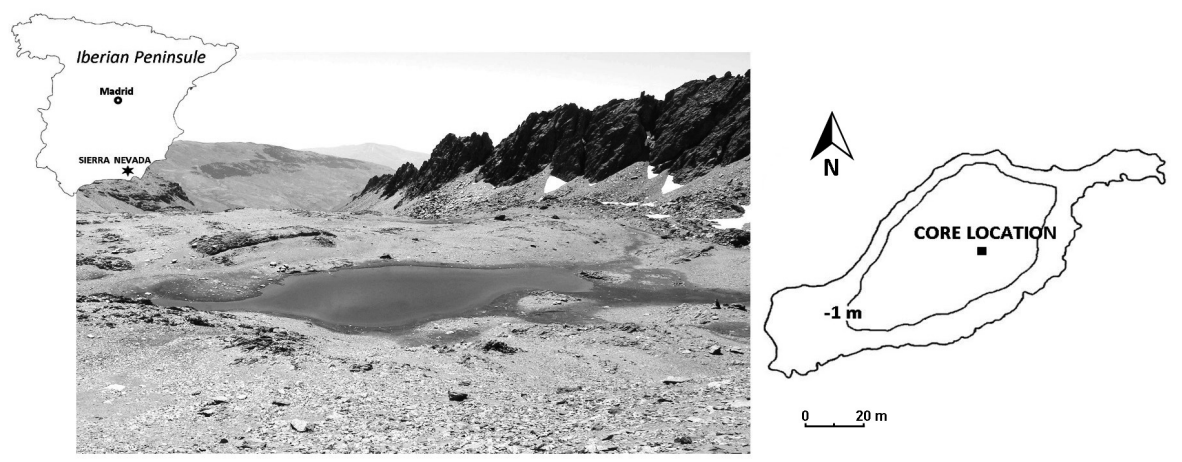

Figure 1. The location of Río Seco Lake in the Sierra Nevada (southern Spain). Left: a photo of the sampling zone; right: a core site. Localización de la laguna de Río Seco de Sierra Nevada (sur de España). A la izquierda, foto de la zona de muestreo. A la derecha, localización del testigo de sedimento. 


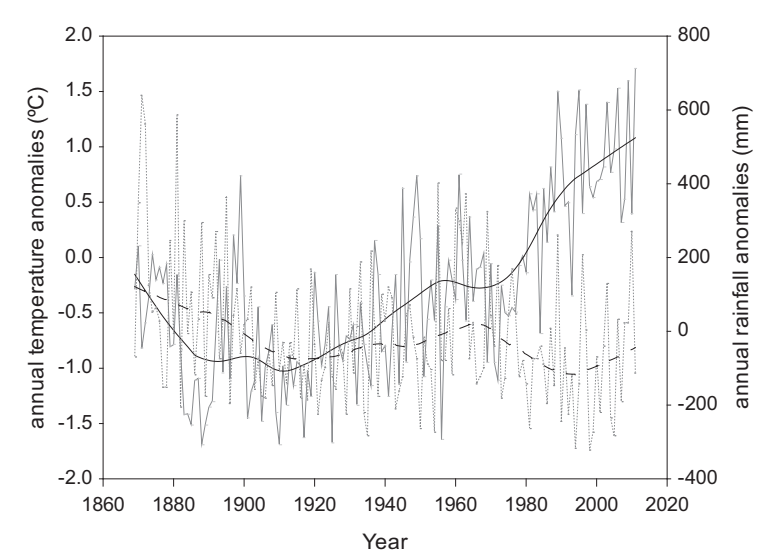

Figure 2. The mean annual air temperature anomalies from the Madrid climate station from 1869 to 2011 (continuous line); anomalies are relative to the 1961-1990 period. The annual rainfall anomalies from the San Fernando climate station from 1839 to 2011 (dashed line); anomalies are relative to the whole period. A LOWESS smoother $(\operatorname{span}=0.25)$ was applied to the climate data to improve the clarity of the figure and highlight trends. Anomalías de temperatura media anual del aire procedente de la estación climática de Madrid desde 1869 a 2011 (línea continua). La anomalías son relativas al período 196190. Las anomalías de la precipitación anual son de la estación climática de San Fernando desde 1839 a 2011 (línea discontinua); las anomalías son relativas al período entero. Para mejorar la claridad de la figura, se ha aplicado un suavizado LOWESS ( span $=0.25$ ) para resaltar las tendencias climáticas.

sealed in sterile "Whirlpack" bags, which were stored and transported in a cold box. In the laboratory, the subsamples were collected at each interval and frozen $\left(-80^{\circ} \mathrm{C}\right)$ until ready for pigment analysis. Subsamples for loss-on-ignition (LOI), C, N, and grain size analysis and for dating and subfossil Cladocera were kept in a cold $\left(4{ }^{\circ} \mathrm{C}\right)$ and dark room until ready for analysis.

\section{Analytical methods}

The sediment was dated by gamma spectroscopy (measuring radionuclide ${ }^{210} \mathrm{~Pb},{ }^{137} \mathrm{Cs}$, and ${ }^{226} \mathrm{Ra}$ ) and alpha spectroscopy $\left({ }^{210} \mathrm{~Pb}\right.$ in deepest part of core) according to the method of Eakins \& Morrison (1978). The dating and sedimentation rate were calculated by using the constant flux: the constant sedimentation (cf:cs) model (Appleby \& Oldfield, 1983). All of these analyses were performed by the Radioisotope Service of the University of Seville (Spain).
The photosynthetic pigments were analysed according to Airs et al., (2001). In brief, thawed samples (between 0.92 and 2.05 wet/wt) were extracted in $10 \mathrm{~mL}$ of acetone $(100 \%)$ by sonication $(10 \mathrm{~min}, 50 / 60 \mathrm{~Hz}$, Ultrason-H, Selecta) under darkness and then centrifuged (5 min, $3500 \mathrm{rpm})$ to remove cellular particle debris. The supernatant was filtered through a cotton wool plug. This was repeated up to a maximum of six times until the supernatant was colourless. The pigment extracts were dried under an $\mathrm{N}_{2}$ stream and then stored at $4{ }^{\circ} \mathrm{C}$ until ready for analysis with high-performance liquid chromatography (HPLC). Before the HPLC analysis, the acetone extracts were dissolved in $500 \mu \mathrm{L}$ of $\mathrm{MeOH}\left(10 \% \mathrm{AcNH}_{4} 5 \mathrm{M}\right)$ and $40 \mu \mathrm{L}$ were injected. The HPLC system was equipped with a 1525 Binary Pump separation module and 2996 photodiode-array detector (Waters, Milford, USA). Chromatography analyses were performed with two Spherisorb S3ODS2 columns $(4.6 \times 150 \mathrm{~mm}, 3 \mu \mathrm{m}$, Waters $)$ using a Spherisorb ODS2 guard cartridge $(4.6 \times 10 \mathrm{~mm}$, $5 \mu \mathrm{m}$, Waters) to maintain the performance of the analytical column. The pigments were eluted using a mobile phase gradient starting with mixture A (MeOH: AcN: $\mathrm{AcNNH}_{4} 0.1 \mathrm{M}$, $80: 15: 5)$ for $5 \mathrm{~min}$, and then from $t=5 \mathrm{~min}$ to $t=100 \mathrm{~min}$, a linear gradient from $100 \%$ mixture A to $100 \%$ mixture $\mathrm{B}(\mathrm{MeOH}$ : $\mathrm{AcN}$ : ethyl acetate, 20:15:65) at a constant flow of $0.7 \mathrm{~mL} / \mathrm{min}$ and following the method of Airs et al., (2001). The compounds were identified from the absorption spectra (Romero-Viana et $a l ., 2009)$ and their concentration was expressed in $\mu \mathrm{g}$ per $\mathrm{g}$ of organic matter, based on specific absorption coefficients published in Jeffrey (1997). The CD/TC (chlorophyll derivative: total carotenoid) ratio was analysed as the sum of all of the breakdown products of native chlorophyll a divided by the sum of all of the carotenoids present throughout the core.

The sediment intervals were subsampled for LOI analyses and placed into pre-weighed crucibles. The LOI was determined by the method of Heiri et al. (2001). The sedimentary C and N content were assessed by combustion in a CARLO ERBA EA 1108 CHNSO Elemental Analyzer 
system. Prior to the grain size analyses, $0.5 \mathrm{~g}$ wet sediment samples were extracted and sieved through $150 \mu \mathrm{m}$ mesh; the size was determined as the cumulative mass percent by $\mathrm{X}$-ray diffraction (XRD) using GALAY model CIS-1, which measures particles ranging from 0 to $150 \mu \mathrm{m}$.

Subfossil cladoceran samples were analysed and identified using the methods described by Szeroczyńska and Sarmaja-Korjonen (2007). In brief, $1 \mathrm{~cm}^{3}$ of fresh sediment of each interval was heated for $20 \mathrm{~min}$ in $10 \% \mathrm{KOH}$ to remove the humic matter and were then washed and sieved through $38 \mu \mathrm{m}$-mesh under tap water, followed by centrifugation ( $5 \mathrm{~min}, 3000 \mathrm{rpm}$ ) to concentrate the fossil cladoceran remains. The Daphnia remains were counted under a light microscope with $20 \times$ magnification; a minimum of 200 subfossil cladoceran remains were counted and identified per interval, and the cladoceran counts were expressed as a percent relative abundance of the total number of individuals counted for each interval.

Long-term climatic instrumental records are not maintained in the Sierra Nevada Mountain range. The closest instrumental data for the highmountain lakes comes from meteorological stations located under $2000 \mathrm{~m}$ a.s.l. and they cover no more than the past 50 years. Moreover, these data series are not reliable because of the numerous gaps and poor quality of the information. One of the longest temperature series in the Sierra Nevada is provided by Cerecillo station (Láujar, Almería), which is located at $1800 \mathrm{~m}$ a.s.l. and has offered data since 1960 , although there are numerous gaps. A strong correlation was found between the Cerecillo temperature series and short homogenized series of mean annual temperatures from meteorological stations (http://www.aemet.es) in low areas, but less than $20 \mathrm{~km}$ from the Sierra Nevada summit (Armilla $r=0.67, p<0.001, n=35$; Lanjarón $r=0.78$, $p<0.001, n=35$ ). Because Armilla and Lanjarón are short series, we also analysed the annual mean air temperatures of ten longer homogenized series from Central and South climate stations across Spain (Staudt et al., 2007). We also found strong correlations (all $r>0.60$ ) between the available data from the Cerecillo, Armilla, and Lanjarón stations and the long-term temperature series of Staudt et al. (2007). This indicated that the annual trends in these long series can be considered representative of the Sierra Nevada region, especially those located in the central and southwest areas of Spain (Cerecillo all $r>0.66$, $n=35$; Armilla all $r>0.82, n=51$ and Lanjarón all $r>0.68, n=54)$. One of the strongest correlations found was with the Madrid temperature series (AEMET 3195), which dates from 1869 , and this series was used to represent annual mean temperature trends in the Sierra Nevada. There are no useful series of rainfall data at the Sierra Nevada summit. Therefore, we analysed the correlation between a short homogenized series of total annual rainfall data from Armilla (since 1940) and five long series from southern Spain. The best correlation was obtained with the series of San Fernando (Naval Base of the Spanish Army, Cádiz, since $1839 r=0.62, p<0.001$, $n=65$ ); hence, this series was used to represent total annual rainfall trends in Sierra Nevada. Esteban-Parra et al. (1997) found that the time course of rainfall is similar among the different areas in the south of Spain. The average of temperature and rainfall data was calculated for each dating interval of the Río Seco Lake core.

\section{Statistical analyses}

STATISTICA v.7 (Statsoft) software was used to test the data normality and Pearson correlations. The Kolmogorov-Smirnov test with Lilliefor's correction was performed to determine the normality of the data distribution. Non-normally distributed variables were log or square-root transformed and Pearson correlation coefficients were used to test the correlations between transformed variables by applying the Bonferroni correction.

We used a redundancy analysis (RDA) to relate the pigment matrix (Hellinger-transformed variables) to the environmental variables, temperature, rainfall and Daphnia relative abundance (log transformed). This analysis was followed by a permutation test produced by the anova.cca function of the Vegan package (Oksanen et al., 2015) in R software (R Development Core Team, 2015). The permutations method was used to test 


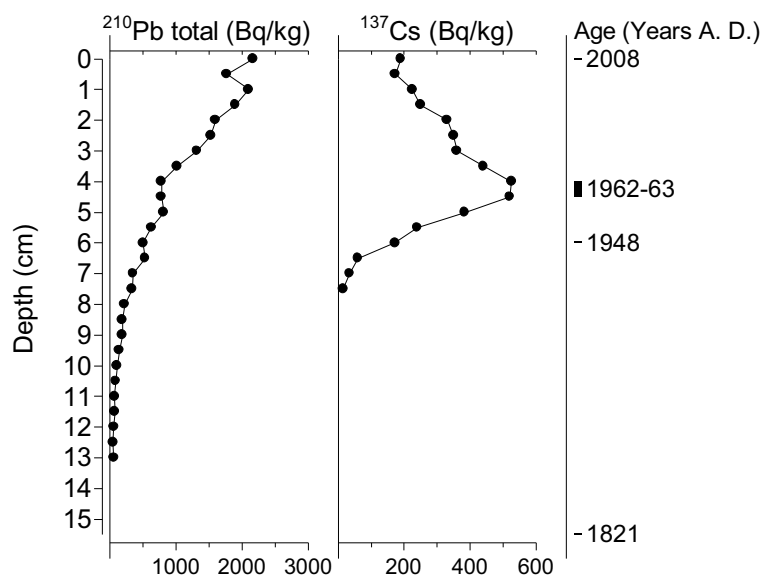

Figure 3. Depth distribution of total ${ }^{210} \mathrm{~Pb}$ and ${ }^{137} \mathrm{Cs}(\mathrm{Bq} / \mathrm{kg})$. The depth of stratigraphic sediment, expressed in $\mathrm{cm}$, is represented on the left y-axis. On the right y-axis, the estimated ages (A. D.) of the sediment are shown. Distribución en profundidad del ${ }^{210} \mathrm{~Pb}$ total ${ }^{137} \mathrm{Cs}(\mathrm{Bq} / \mathrm{kg})$. La profundidad del sedimento estratigráfico, expresado en $\mathrm{cm}$, está representado en el eje $Y$ izquierdo. En el eje $Y$ derecho, la edad estimada (A. D.) del sedimento.

for significance in the canonical analysis (e.g., redundancy analysis) (Legendre \& Legendre, 1998; Borcard et al., 2011). Permutation is the method of choice because it avoids making assumptions regarding the distribution of the data (Legendre \& Legendre, 1998).

The uppermost sediment sample $(0-0.5 \mathrm{~cm})$ was eliminated from the statistical analyses because it could not be reliably identified as exclusively sedimentary pigment.
Zonation of the stratigraphic profiles of the pigment concentrations was performed by a cluster analysis with a constrained incremental sum of squares (CONISS), square root transformation of data, and chord distance as the dissimilarity coefficient using Tiliagraph View (TGView) version 2.02 (Grimm, 2004) and determining the number of significant zones by means of the broken stick model (Bennett, 1996).

\section{RESULTS}

\section{Climate data}

The mean annual air temperature data show a marked warming trend since the 1920 s that was especially pronounced after the early 1970s. The second half of the $19^{\text {th }}$ century was wet and reached a maximum in approximately 1860-70. Since the late $19^{\text {th }}$ century, rainfall has progressively decreased, except during the 1960s, and the last 40 years have been especially dry (Fig. 2).

\section{Chronological model}

The ${ }^{210} \mathrm{~Pb}$ total activity profile shows a decreasing trend. The ${ }^{210} \mathrm{~Pb}$ dated sediment core represents 187 years of accumulation, and the deepest part of the core was dated at 1821 A. D. The sedimentation rates were $0.9-1.1 \mathrm{~mm}^{\text {years }}{ }^{-1}$
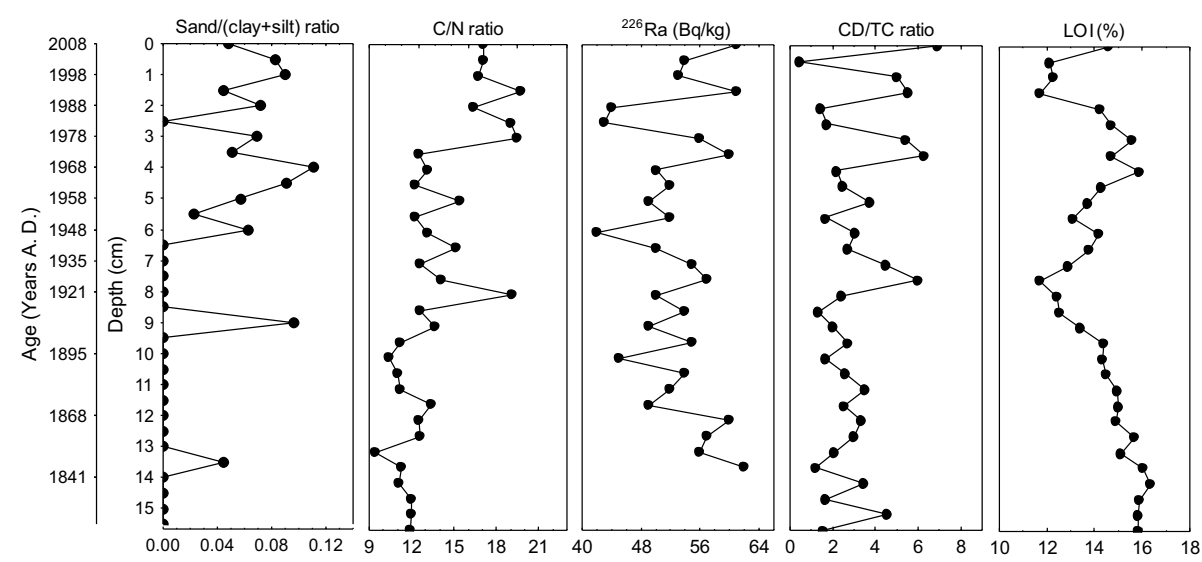

Figure 4. The Sand/(clay + silt) ratio, $\mathrm{C} / \mathrm{N}$ ratio, ${ }^{226} \mathrm{Ra}$ activity, $\mathrm{CD} / \mathrm{TC}$ ratio and LOI (\%) in the sediment of Río Seco Lake. El índice arena/limo + arcilla, índice C/N, actividad de ${ }^{226} \mathrm{Ra}$, índice CD/TC y LOI (\%) en el sedimento de la laguna de Río Seco. 
Table 1. The results of the redundancy analyses (RDA) with temperature, rainfall and the relative abundance of Daphnia pulex gr. as predictor variables and pigment data as response variables. Resultados del análisis de redundancia (RDA) con la temperatura, precipitación y abundancia relativa de Daphnia pulex gr. como variables predictoras; y el conjunto de pigmentos como variables respuesta.

\begin{tabular}{lcccc}
\hline & Df & Variance & F & $p$-values \\
\hline Temperature & 1 & 1.007 & 5.010 & 0.003 \\
Rainfall & 1 & 0.141 & 0.705 & 0.542 \\
Daphnia & 1 & 0.484 & 2.408 & 0.059 \\
Residual & 19 & 3.819 & & \\
\hline
\end{tabular}

Adjusted $R^{2}=0.148$

from 0 to $6 \mathrm{~cm}$ depth (from ca. A. D. 2008 to A. D. 1948) and 0.7-0.8 $\mathrm{mm} \mathrm{years}^{-1}$ from $6 \mathrm{~cm}$ to $15.5 \mathrm{~cm}$ depth (from ca. A. D. 1948 to A. D. 1821). The ${ }^{137} \mathrm{Cs}$ activity versus the depth profile showed a single significant peak between 4 and $4.5 \mathrm{~cm}$, which corresponded to $1962-63$ by the estimated ${ }^{210} \mathrm{~Pb}$ age (Fig. 3).

\section{Sedimentary proxy record}

The atomic $\mathrm{C} / \mathrm{N}$ ratio, which yields information on the source of the organic matter, ranged between 10.39 and 19.73 and showed a significant increase from the 1970s onward. The sand/ $($ clay + silt) ratio showed strong fluctuations over time with a significant increase from the 1940s to the present. The mean ${ }^{226} \mathrm{Ra}$ activity throughout the stratigraphic profile was $50 \mathrm{~Bq} / \mathrm{kg}$ with highest values in the uppermost intervals (Fig. 4).

The Río Seco Lake sediment sample exhibited a narrow variety of sedimentary photosynthetic pigments (Fig. 5). Twenty different pigments were identified, including native chlorophyll $\mathrm{a}$ and $\mathrm{b}$ and their degradation products, which were pheophytins, pyropheophytins and pheophorbides. The most abundant carotenoids were zeaxanthin, echinenone and myxoxanthophyll (specific pigments from cyanobacteria), fucoxanthin and diadinoxanthin (from diatoms and

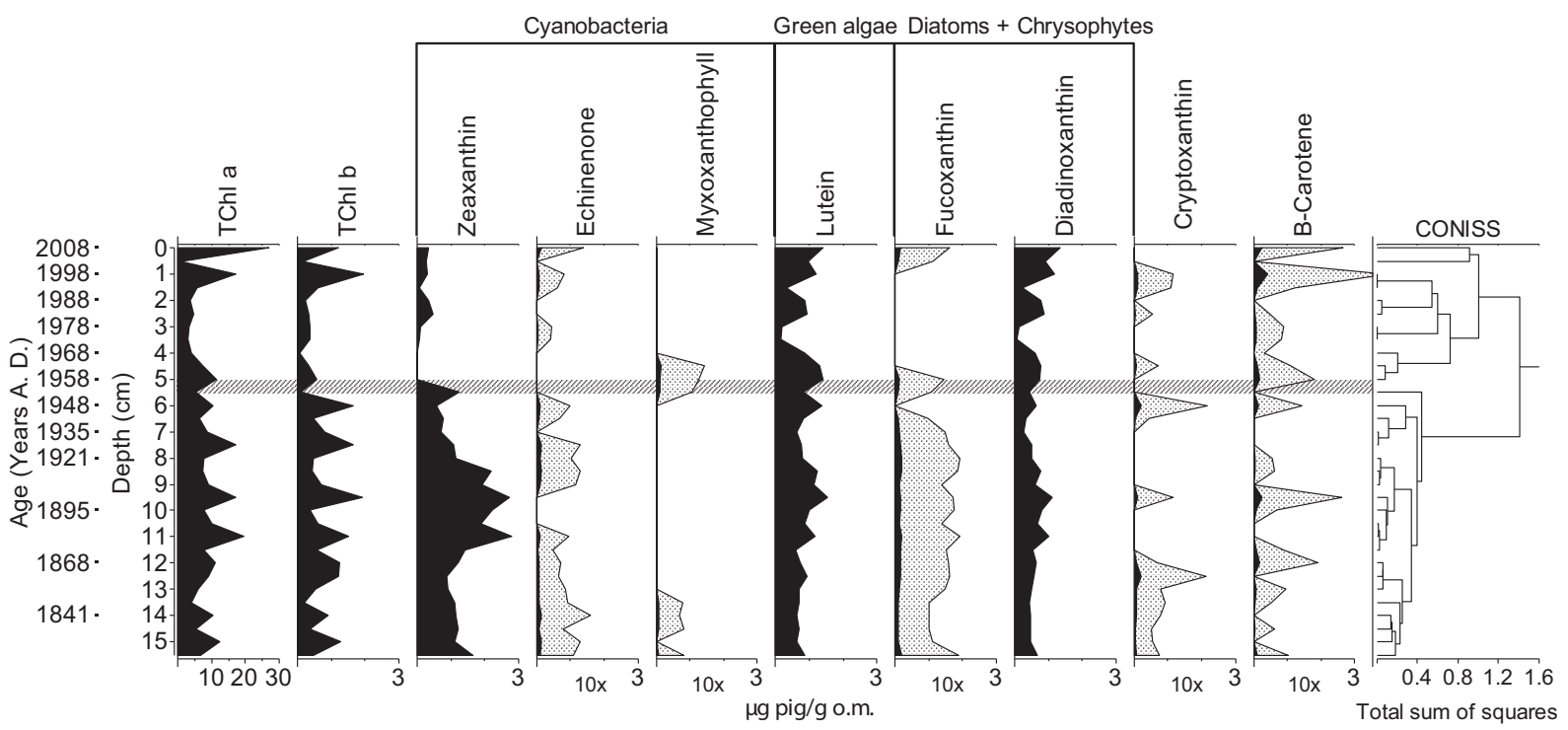

Figure 5. A stratigraphic profile of specific pigments (TChl a, TChl b, zeaxanthin, echinenone, myxoxanthophyll, lutein, fucoxanthin, diadinoxanthin, cryptoxanthin and $\beta$-carotene). All of the compounds are expressed as $\mu \mathrm{g}$ pigment/g of organic matter. The exaggerated areas are dotted (each exaggeration scale is indicated below). A horizontal line delineates different zones determined by cluster analysis using the Constrained Incremental Sum of Squares (CONISS). The uppermost sediment sample (0-0.5 cm) is also shown, although it is not exclusively composed of sedimentary pigments. Perfil estratigráfico de pigmentos específicos (TChl a, TChl $b$, zeaxantina, equinenona, mixoxantofila, luteína, fucoxantina, diadinoxantina, criptoxantina y $\beta$-caroteno). Todos los compuestos están expresados en microgramos de pigmentos por gramos de materia orgánica. Las áreas de exageración están indicadas con un patrón de puntos (la escala de exageración está indicada debajo de cada columna). La línea horizontal delimita diferentes zonas establecidas por el análisis cluster usando el análisis de agrupamiento (CONISS). La muestra superficial (0-0.5 cm) se presenta en la gráfica, pero no es considerado exclusivamente como pigmentos sedimentarios. 
chrysophytes), and lutein (from chlorophytes). Less abundant carotenoids included cryptoxanthin (from chlorophytes and cyanobacteria) and b-carotene (from all of the algal groups).

Studying the main patterns in the pigment composition in relation to the environmental variables, we found that the pigment matrix was only significantly related with temperature, although the relative abundance of Daphnia was marginally related (Table 1$)$. The stratigraphic pigment signal in Rio Seco Lake shows a vertical profile marked by two distinct zones (Fig. 5). The lower zone from 1820 to the 1950 s, is characterized by an abundant signal of carotenoids that are specific indicators of the cyanobacteria community (mainly zeaxanthin and echinenone), which represent approximately $45 \%$ of the total carotenoid concentration in the sediment profile. In the upper zone, there is a drastic reduction in the cyanobacteria community signal. Hence, there has

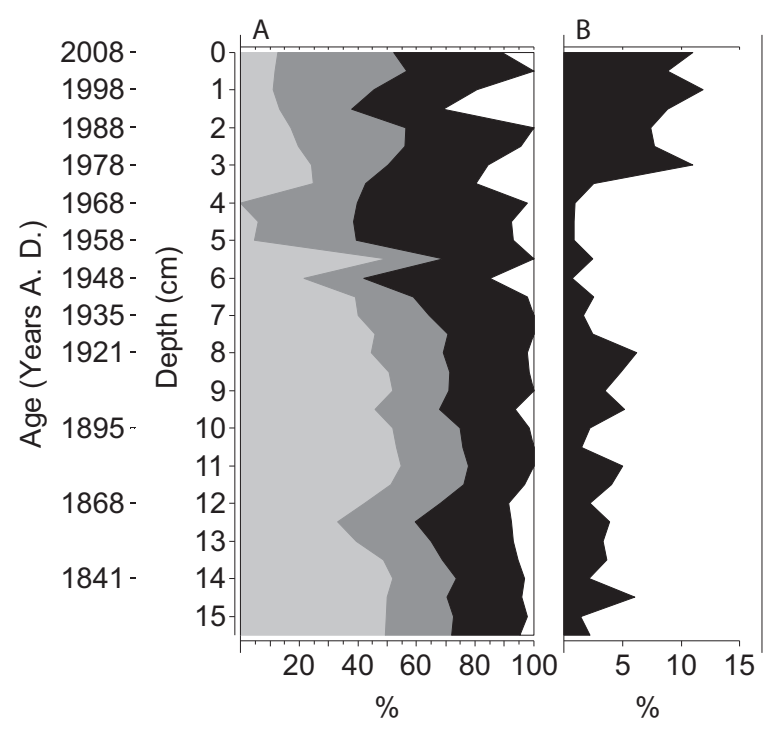

Figure 6. (A) The percentage contribution of the sum of the main algal carotenoids; from left to right: zeaxanthin, echinone and myxoxanthophyll (light grey), diadinoxanthin and fucoxanthin (medium grey), lutein (black) and other carotenoids (white). (B) The relative abundance, expressed as a percentage, of Daphnia pulex gr. in the sediment of Río Seco Lake. (A) Porcentaje de los principales carotenoides, de izquierda a derecha: zeaxantina, echinenona y mixoxantofila (gris claro), diadinoxantina y fucoxantina (gris oscuro), luteina (negro) y otros carotenoides (blanco). (B) Abundancia relativa, expresada en porcentajes, de Daphnia pulex gr. en el sedimento de la laguna de Río Seco. been a sharp decrease in the contribution percentage of cyanobacteria indicator pigments since the 1940s in Río Seco Lake and a marked increase in the relative abundance of the Daphnia pulex group since the late 1970s (Fig. 6). The concentration of zeaxanthin was higher during wet and cold periods than during dry and warm periods over the past few decades (Fig. 7). The cyanobacteria pigment profile was negatively correlated with temperature values $(r=-0.54$, $p<0.05)$. There was a major reduction in the total sum of chlorophyll $\mathrm{a}$ and $\mathrm{b}$ and the concentration of some carotenoids (mainly fucoxanthin) between the late 1950s and the 1990s. The $\mathrm{CD} / \mathrm{TC}$ ratio ranged from 0.4 to 6.9 with the highest values in the uppermost layers (Fig. 4). The TC values showed a significant negative correlation with the $\mathrm{C} / \mathrm{N}$ ratio $(r=-0.46, p<0.05)$.

\section{DISCUSSION}

The low variety and concentration of sedimentary pigments in the Rio Seco Lake sediment reflects the typical primary production of oligotrophic and high-mountain lakes (Lami et al., 2000; Kamenik et al., 2000; Buchaca et al., 2005). The presence of specific photosynthetic pigments throughout the stratigraphic sedimentary profile indicates that cyanobacteria, diatoms, chrysophytes and chlorophytes have been the most abundant algal groups in this lake over the past 200 years. It is noteworthy to mention that several years of plankton sampling in Río Seco Lake have demonstrated that Synechococcus nidulans is one of the dominant planktonic species (Conde-Porcuna et al., 2014) and is the most important planktonic cyanobacteria species. Although we have not quantified the abundance of benthic cyanobacteria species in Río Seco Lake, occasional samplings show their low contribution to the benthic algal community. Benthic cyanobacteria species are filamentous species belonging to the genera Oscillatoria, Anabaena, Nostoc, and Calothrix and non-filamentous species of the genus Aphanothece. The endosymbiont cyanobacteria Paulinella chromatophora is also found in the lake (Sánchez-Castillo, 1988). 
The green algae assemblage shows a major contribution rather than other algae groups; and they largely comprise planktonic Chlorophyceae species, notably the epibiont Korshikoviella gracilipes and benthic filaments of a species of Zygnemataceae (Pérez-Martínez et al., 2013). The present data show a significant abundance of diatom-derived pigments, such as diadinoxanthin and fucoxanthin, and marker pigments of diatoms, chrysophytes and dinoflagellates (Leavitt \& Hodgson, 2001; Buchaca \& Catalan, 2007). Studies of siliceous subfossil samples in Río Seco Lake showed a predominance of benthic diatom species and a relatively low abundance of stomatocyst types (Pérez-Martínez et al., 2012). The presence of dinoflagellates in the plankton of Río Seco Lake is almost exclusively reduced due to a low concentration of Gymnodinium sp., whereas species of the genus Chromulina only show a peak of abundance after the thaw (Barea-Arco et al., 2001). Therefore, the diadinoxanthin and fucoxanthin in Río Seco Lake is mainly attributed to benthic diatoms. Other marker pigments of chrysophytes (violaxanthin) and dinoflagellates (peridinin and dinoxanthin) were not detected in our sediment record.

The most significant changes observed in the pigment stratigraphy of Río Seco Lake are the decrease in zeaxanthin pigment from the 19th century to the present time and the decrease in chlorophylls and labile carotenoids from the 1960 s to the early 1990s. Zeaxanthin are observed in large amounts in picocyanobacteria than in other cyanobacterial groups (Bonilla et al., 2005; Romero-Viana et al., 2009), and S. nidulans is the main planktonic species of cyanobacteria in Río Seco Lake. Hence, the observed decrease of zeaxanthin in Río Seco

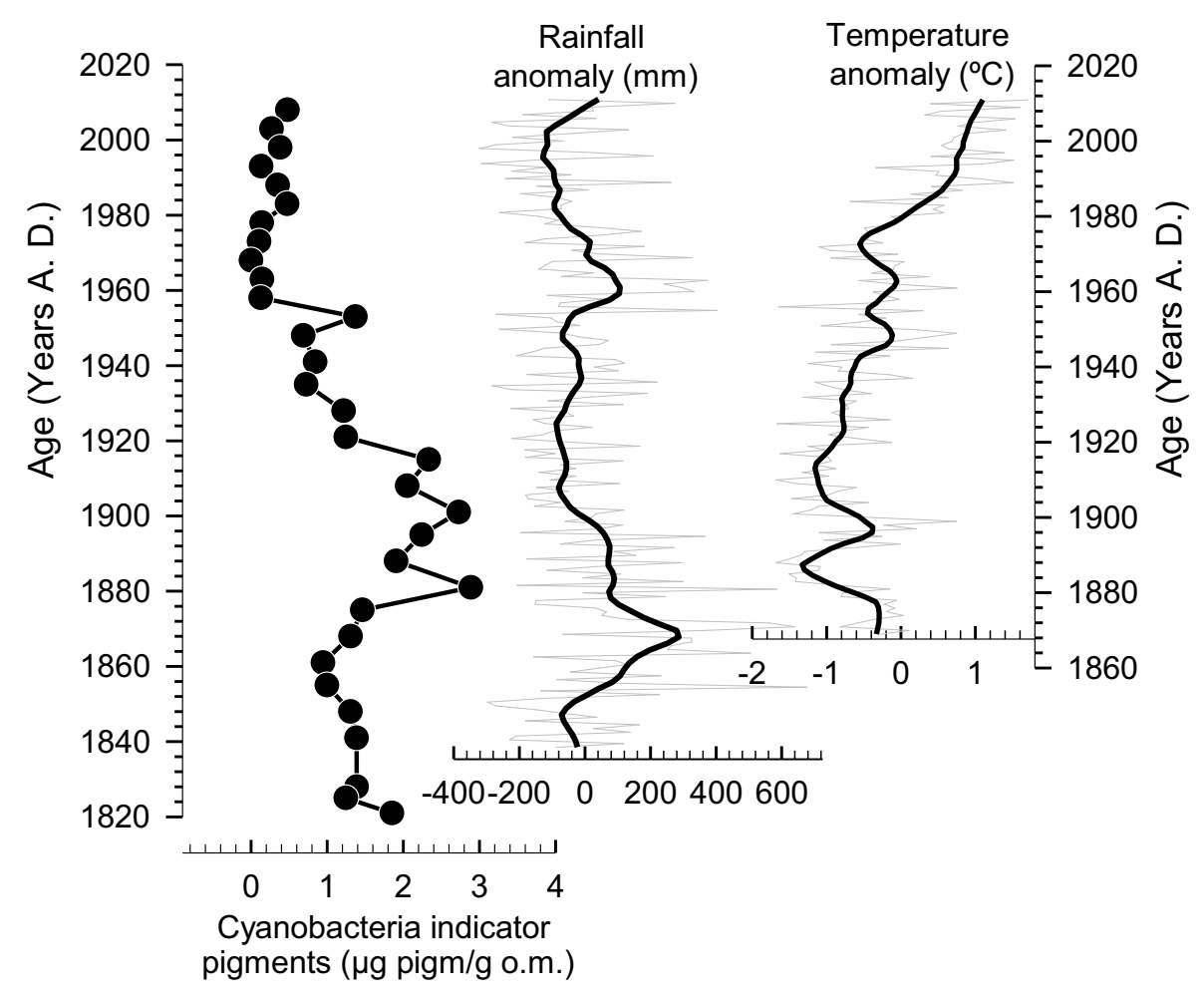

Figure 7. A sedimentary profile of cyanobacteria indicator pigments and climate data representing the mean temperature and rainfall anomalies for the dating intervals of Río Seco Lake. A LOESS smoother (span =0.1) was applied to the climate data. Perfil estratigráfico de pigmentos indicadores de cianobacterias junto con los datos climáticos. Se representa la media de las anomalías de temperatura y precipitación ajustados a los intervalos de datación de la laguna de Río Seco. Se ha aplicado un suavizado LOESS ( span $=0.1)$ a las series climáticas. 
Lake can be mainly attributed to a decrease in picoplanktonic cyanobacteria species, such as $S$. $n i$ dulans, which would be controlled by abiotic factors (e.g., temperature and/or nutrients) or by top-down resource control. According to the classification of Reynolds et al. (2002), picoplanktonic cyanobacteria species are tolerant to low nutrient water and sensitive to grazing. With regard to nutrients, the decrease in livestock activity in the high mountain of Sierra Nevada since the late 1950s, which is shown by the decrease in herbivore dung fungus Sporormiella (Anderson et al., 2011), may have reduced the nutrient inputs into the lake. However, the increasing number of visitors and recreation activities since the 1960 s is likely to have increased nutrient input to the lake offsetting the above reduction. The atmospheric deposition of $\mathrm{N}$ and $\mathrm{P}$ may have increased in the last decades because of pollution and Saharan dust events. The deposition N:P ratio is lower than 16 (Redfield ratio) during the spring-summer period (Morales-Baquero et al., 2006b), which could have favoured cyanobacteria rather than undermine them. Hence, we cannot propose nutrient availability as a direct cause of zeaxanthin changes based on the available data. Alternatively, the zeaxanthin concentration in Río Seco Lake sediment may have been related to climate conditions. This is supported by the significant correlation between cyanobacteria indicator pigments with temperature and by the significant relationship of global pigment data with temperature (RDA analyses). Reduced water residence time and nutrient limitation during cold and wet periods may have favoured species with elevated growth rates and high competitive ability for nutrients, such as picoplanktonic species (Schlesinger et al., 1981; Reynolds et al., 2002; Rigosi et al., 2014), whereas no advantage is obtained under warmer and drier conditions. Additionally, under the latter conditions, picoplanktonic species may have suffered from high grazing pressure in Río Seco Lake. Morales-Baquero et al. (2006a) showed that the constrained zooplankton growth in Río Seco Lake during the cold years produced a weaker top-down control of phytoplankton biomass and therefore a higher algal biomass in comparison to warmer years. Likewise, the low concentration of zeaxanthin since the 1980s could also be attributed to an increase in grazing pressure due to a greater abundance of zooplankton; this hypothesis is supported by the marked increase since the late 1970s in the relative abundance of the efficient grazer D. pulicaria, which is the only Daphnia species of the pulex group present in Río Seco Lake and the main planktonic Cladocera found in the sedimentary profile.

Similarly, grazing on other important planktonic algal groups could be expected to reduce pigments in Río Seco Lake such as green algae. However, the main chlorophyte planktonic species is $K$. gracilipes, an epibiont species on $D$. pulicaria with which it shows a mutualistic relationship and its density is therefore favoured by a higher $D$. pulicaria density (Barea-Arco et al., 2001; Pérez-Martínez et al., 2001). The other main algal group in Río Seco Lake is represented by diatoms, which do not seem to be affected by zooplankton herbivorous grazing because they are mainly found in the benthos and littoral zone. Therefore, the changes observed in the zeaxanthin concentration may result from the effect of climate-driven factors on herbivorous grazing pressure and water residence time.

An increase in the cyanobacteria sedimentary signal over recent decades has been reported in many European arctic and alpine lakes in the MOLAR project (Lami et al., 1998, 2000). A warming-linked increase in cyanobacteria has been repeatedly recorded and predicted (Reynolds, 2006; Jöhnk et al., 2008; Gallina et al., 2011) because of the benefits they obtain in warmer water and a stabilized water column (Carey et al., 2012; Rigosi et al., 2014). These studies mainly refer to filamentous cyanobacteria species in relatively deep lakes that stratify in the summer time. However, Río Seco Lake is a shallow lake that does not stratify, and the cyanobacteria are mainly picoplanktonic species, which are affected by other factors including grazing pressure.

Another major change observed in Río Seco sedimentary pigment is the decrease in total chlorophylls and fucoxanthin from the early 1960 s to the 1990s. This is a striking result 
given the numerous reports of an increase in primary production due to longer summer growing seasons and higher nutrient input in remote lakes under recent warming conditions (Battarbee et al., 2002; Michelutti et al., 2005; Reuss et al., 2010). These discrepancies may be explained by the substantial human disturbances in the watershed of Río Seco Lake since the 1960s. The intense activity of mountaineers and vehicle traffic around the lake likely resulted in a considerable alteration of the shoreline and the surrounding area. Thus, increases in the proportion of sand and the sedimentation rate since the $1940 \mathrm{~s}$, and the higher ${ }^{226} \mathrm{Ra}$ activity detected since the $1960 \mathrm{~s}$, might indicate the occurrence of shoreline erosion that facilitated the mobilization and transport of inorganic particulate matter from the land to the water (Lami et al., 1998; Toro \& Granados, 2002; Brenner et al., 2004). The marked increase in the $\mathrm{C} / \mathrm{N}$ ratio over the past few decades indicates the inputs of organic matter into the lake. Their negative correlation with total carotenoids and the peaks of the $\mathrm{CD} / \mathrm{TC}$ ratio in the uppermost layers of Río Seco Lake sediment indicate inputs of carotenoid-poor pigmented organic matter (Gorham \& Sanger, 1972; Sanger, 1988), which probably consists of littoral plant fragments (macroscopic bryophytes remains were observed throughout the core) and/or littoral sediment from the dried shoreline. This would have resulted in a dilution of the concentration of chlorophylls and labile carotenoids.

Finally, the two high peaks of the sand/ (clay + silt) ratio around the 1960s and 1990s may be due to the building and destruction, respectively, of the mountain hut and road. The drop in sedimentary pigment concentration during the second interval might have been produced by the huge amounts of external material generated by the demolition, which clouded the lake and had a major effect on all of the organisms including algae. A reduction in the ${ }^{210} \mathrm{~Pb}$ profile was also observed, which reflected an abrupt change in the sediment composition.

The most important change in Rio Seco Lake over the past two centuries occurred from the 1950s onward. Unlike other alpine and highmountain lakes, where an increase in cyano- bacteria abundance has been reported over recent decades, the sedimentary pigments in Rio Seco Lake indicate the opposite trend. Change in the algae community in Rio Seco Lake appears to be driven by factors linked to global warming, such as increased zooplankton grazing pressure and reduced water residence time. Human disturbance have been recognized in the core profile, resulting in an intense erosion of the catchment and consequent dilution of chlorophylls and labile carotenoids over recent decades. This is the first study on sedimentary pigments in Sierra Nevada National Park, and its results have been served to elucidate how a high-mountain lake responds to natural and human processes over a 200-year time-scale.

\section{ACKNOWLEDGMENTS}

The authors are grateful to their colleagues who collaborated in the field sampling and laboratory work. They would also like to thank the AEMET and San Fernando Naval Base of the Spanish Army for the meteorological data, Dr. María Jesús Esteban Parra and the Department of Applied Physics of the University of Granada for climatic data, and Dr. Francisco Javier Bonet García and the Andalusian Environmental Centre (CEAMA) for providing local climatic data. They would also like to thank two anonymous reviewers for making valuable suggestions to earlier drafts of this study. Logistical support was provided by the Scientific Instrumental Service of Experimental Station of El Zaidín (EEZ-CSIC) and the Center for Scientific Instrumentation of the University of Granada. Financial support was provided by MMA Project 87/2007 and MINECO Project CGL2011-23483 to C. Pérez-Martínez and a FPU fellowship to L. Jiménez from the Spanish Ministry of Education and Science.

\section{REFERENCES}

AIRS, R. L., J. E. ATKINSON \& B. J. KEELY. 2001. Development and application of a high resolution liquid chromatographic method for the analysis of 
complex pigment distributions. Journal of Chromatography A, 917: 167-177.

ALRIC, B., J. P. JENNY, V. BERTHON, F. ARNAUD, C. PIGNOL, J. L. REYSS, P. SABATIER \& M. E. PERGA. 2013. Local forcings affect lake zooplankton vulnerability and response to climate warming. Ecology, 94: 2767-2780.

ANDERSON, R. S., G. JIMÉNEZ-MORENO, J. S. CARRIÓN \& C. PÉREZ-MARTÍNEZ. 2011. Holocene vegetation history from Laguna de Río Seco, Sierra Nevada, southern Spain. Quaternary Science Reviews, 30: 1615-1629.

APPLEBY, P. G. \& F. OLDFIELD. 1983. The assessment of ${ }^{210} \mathrm{~Pb}$ data from sites with varying sediment accumulation rates. Hydrobiologia, 103: 29 35.

BAREA-ARCO,J., C. PÉREZ-MARTÍNEZ \& R. MORALES-BAQUERO. 2001. Evidence of a mutualistic relationship between an algal epibiont and its host Daphnia pulicaria. Limnology and Oceanography, 46: 871-881.

BATTARBEE, R. W., R. THOMPSON, J. CATALAN, J. A. GRYTNES \& H. J. B. BIRKS. 2002. Climate variability and ecosystem dynamics of remote alpine and arctic lakes: the MOLAR project. Journal of Paleolimnology, 28: 1-6.

BATTARBEE, R. W., M. KERNAN \& N. ROSE. 2009. Threatened and stressed mountain lakes of Europe: Assessment and progress. Aquatic Ecosystem Health \& Management, 12 (2): 118-128.

BENNETT, K. D. 1996. Determination of the number of zones in a biostratigraphical sequence. New Phytologist, 132: 155-70.

BONILLA, S., V. VILLENEUVE. \& W. F. VINCENT. 2005. Benthic and planktonic algal communities in a high arctic lake: pigment structure and contrasting responses to nutrient enrichment. Journal of Phycology, 41: 1120-1130.

BORCARD, D., F. GILLET \& P. LEGENDRE. 2011. Numerical Ecology with R. Springer. New York.

BRENNER, M., C. L. SCHELSKE \& W. F. KENNEY. 2004. Inputs of dissolved and particulate 226Ra to lakes and implications for ${ }^{210} \mathrm{~Pb}$ dating recent sediments. Journal of Paleolimnology, 32: 53-66.

BUCHACA, T., M. FELIP \& J. CATALAN. 2005. A comparison of HPLC pigment analyses and biovolume estimates of phytoplankton groups in an oligotrophic lake. Journal of Plankton Research, 27(1): 91-101.
BUCHACA, T \& J. CATALAN. 2007. Factors influencing the variability of pigments in the surface sediments of mountain lakes. Freshwater Biology, 52: $1365-1379$.

CAREY, C. C., B. W. IBELINGS, E. P. HOFFMANN, D. P. HAMILTON \& J. D. BROOKES. 2012. Ecophysiological adaptations that favour freshwater cyanobacteria in a changing climate. Water Research, 46: 1394-1407.

CATALAN, J., S. PLA, M. RIERADEVALL, M. FELIP, M. VENTURA, T. BUCHACA, L. CAMARERO, A. BRANCELJ, P. G. APPLEBY, A. LAMI, J. A. GRYTNES, A. AGUSTÍ-PANAREDA \& R. THOMPSON. 2002. Lake Redó ecosystem response to an increasing warming in the Pyrenees during the twentieth century. Journal of Paleolimnology, 28: 129-145.

CATAlAN, J., S. PLA-RABÉS, A. P. WOLFE, J. P. SMOL, K. M. RÜHLAND, N. J. ANDERSON, J. KOPÁČEK, E. STUCHLÍK, R. SCHMIDT, K. A. KOINIG, L. CAMARERO, R. J. FLOWER, O. HEIRI, C. KAMENIK, A. KORHOLA, P. R. LEAVITT, R. PSENNER \& I. RENBERG. 2013. Global change revealed by palaeolimnological records from remote lakes: a review. Journal of Paleolimnology, 49: 513-535.

CONDE-PORCUNA, J. M., E. RAMOS-RODRÍGUEZ \& C. PÉREZ-MARTÍNEZ. 2014. In situ production of empty ephippia and resting eggs by an obligate parthenogenetic Daphnia population. Journal of Plankton Research, 36(1): 157-169.

CORBETT, L. B. \& J. S. MUNROE. 2010. Investigating the influence of hydrogeomorphic setting on the response of lake sedimentation to climatic changes in the Uinta Mountains, Utah, USA. Journal of Paleolimnology, 44: 311-325.

DOUGLAS, M. S. V., J. P. SMOL \& W. BLAKE Jr. 1994. Marked post-18th century environmental change in high-arctic ecosystems. Science, 266: 416-419.

EAKINS, J. D. \& R. T. MORRISON. 1978. A new procedure for the determination of lead-210 in lake and marine sediments. The International Journal of Applied Radiation and Isotopes, 29: 531-536.

ESTEBAN-PARRA, M. J., F. S. RODRIGO, D. POZO \& Y. CASTRO-DÍEZ. 1997. Changes of rainfall in Andalusia since the last century. 10th Conference on Applied Climatology. October 20-24, 1997. Reno, Nevada: 271-274.

GALLINA, N., O. ANNEVILLE \& M. BENISTON. 2011. Impacts of extreme air temperatures on 
cyanobacteria in five deep peri-alpine lakes. Journal of Limnology, 70: 186-196.

GARCÍA-JURADO, F., F. JIMÉNEZ-GÓMEZ \& F. GUERRERO. 2011. Effects of a dry period on the limnological characteristics of a Mediterranean high mountain lake. Limnetica, 30: 5-16.

GORHAM, E. \& J. E. SANGER. 1972. Fossil pigments in the surface sediments of a meromictic lake. Limnology and Oceanography, 17: 618-622.

GRIMM, E. C. 2004. Tilia and TG View Version 2.0.2. Illinois State Museum Research and Collection Center Springfield.

HAUER, F. R., J. S. BARON, D. H. CAMPBELL, K. D. FAUSCH, S. W. HOSTETLER, G. H. LEAVESLEY, P. R. LEAVITT, D. M. MCKNIGHT \& J. A. STANFORD. 1997. Assessment of climate change and freshwater ecosystems of the Rocky Mountains, USA and Canada. Hydrological Processes, 11: 903-924.

HEIRI, O., A. F. LOTTER \& G. LEMCKE. 2001. Loss on ignition as a method for estimating organic and carbonate content in sediments: reproducibility and comparability of results. Journal of Paleolimnology, 25: 101-110.

HOBBS, W. O., R. J. TELFORD, H. J. B. BIRKS, J. E. SAROS, R. R. O. HAZEWINKEL, B. B. PERREN, E. SAULNIER-TALBOT \& A. P. WOLFE. 2010. Quantifying recent ecological changes in remote lakes of North America and Greenland using sediment diatom assemblages. PLoS One, 5(4): e10026.

HUNDEY, E. J., K. A. MOSER, F. J. LONGSTAFFE, N. MICHELUTTI \& R. HLADYNIUK. 2014. Recent changes in production in oligotrophic Uinta Mountain lakes, Utah, identified using paleolimnology. Limnology and Oceanography, 59: 19872001.

JEFFREY, S. W. 1997. Chlorophyll and carotenoid extinction coefficients. In Phytoplankton pigments in Oceanography. S. W. Jeffrey, R. F. C. Mantoura and S. W. Wright (eds): 595-596. Unesco Publishing, Paris, France.

JÖHNK, K. D., J. HUISMAN, J. SHARPLES, B. SOMMEIJER, P. M. VISSER \& J. M. STROOM. 2008. Summer heatwaves promote blooms of harmful cyanobacteria. Global Change Biology, 14: 495-512.

KAMENIK, C., K. A. KOINIG, R. SCHMIDT, P. G. APPLEBY, J. A. DEARING, A. LAMI, R. THOMPSON \& R. PSENNER. 2000. Eight hundred years of environmental changes in a high Alpine lake (Gossenköllesee, Tyrol) inferred from sediment records. Journal of Limnology, 59 (Suppl. 1): 43-52.

KOINIG, K. A., C. KAMENIK, R. SCHMIDT, A. AGUSTÍ-PANAREDA, P. APPLEBY, A. LAMI, M. PRAZAKOVA, N. ROSE, $\varnothing$. A. SCHNELL, R. TESSADRI, R. THOMPSON \& R. PSENNER. 2002. Environmental changes in an alpine lake (Gossenköllesee, Austria) over the last two centuries -the influence of air temperature on biological parameters. Journal of Paleolimnology, 28: 147-160.

LAMI, A., P. GUILIZZONI, A. MARCHETTO, R. BETTINETTI \& D. J. SMITH. 1998. Palaeolimnological evidence of environmental changes in some high altitude Himalayan lakes (Nepal). Memorie dell'Istituto Italiano di Idrobiologia, 57: 107130.

LAMI, A., P. GUILIZZONI \& A. MARCHETTO. 2000. High resolution analysis of fossil pigments, carbon, nitrogen and sulphur in the sediment of eight European Alpine lakes: the MOLAR project. Journal of Limnology, 59 (Suppl. 1): 15-28.

LAMI, A., S. TURNER, S. MUSAZZI, S. GERLI, P. GUILIZZONI, N.L. ROSE, H. YANG, G. WU \& R. YANG. 2010. Sedimentary evidence for recent increases in production in Tibetan plateau lakes. Hydrobiologia, 648: 175-187.

LEAVITT, P. R. \& D. A. HODGSON. 2001. Sedimentary pigments. In: Tracking Environmental Change Using Lake Sediments. Volume 3: Terrestrial, Algal, and Siliceous Indicators. J. P. Smol, H. J. B. Birks \& W. M. Last (eds.): 295-325. Kluwer Academic Publishers, Dordrecht. The Netherlands.

LEGENDRE, P. \& L. LEGENDRE. 1998. Numerical Ecology. Second English edition. Elsevier. Amsterdam.

LOTTER, A. F. \& H. J. B. BIRKS. 1997. The separation of the influence of nutrients and climate on the varve time-series of Baldeggersee, Switzerland. Aquatic Sciences, 59: 362-375.

LOTTER, A. F., H. J. B. BIRKS, W. HOFMANN \& A. MARCHETTO. 1997. Modern diatom, cladocera, chironomid and chrysophyte cyst assemblages as quantitative indicators for the reconstruction of past environmental conditions in the Alps. I. Climate. Journal of Paleolimnology, 18: 395-420.

LUOTO, T. P. \& L. NEVALAINEN. 2013. Long-term water temperature reconstructions from mountain lakes with different catchment and morphometric features. Scientific Reports, 3: 2488. 
MICHELUTTI, N., A. P. WOLFE, R. D. VINEBROOKE, B. RIVARD \& J. P. BRINER. 2005. Recent primary production increases in arctic lakes. Geophysical Research Letters, 32: L19715.

MICHELUTTI, N., A. P. WOLFE, C. A. COOKE, W. O. HOBBS, M. VUILLE \& J. P. SMOL. 2015. Climate change forces new ecological states in tropical Andean lakes. PLoS One, 10(2): e0115338.

MORALES-BAQUERO, R., P. CARRILLO, J. BAREA-ARCO, C. PÉREZ-MARTÍNEZ \& M. VILLAR-ARGAIZ. 2006a. Climate-driven changes on phytoplankton-zooplankton coupling and nutrient availability in high mountain lakes of Southern Europe. Freshwater Biology, 51: 989-998.

MORALES-BAQUERO, R., E. PULIDO-VILLENA \& I. RECHE. 2006b. Atmospheric inputs of phosphorus and nitrogen to the southwest Mediterranean region: Biogeochemical responses of high mountain lakes. Limnology \& Oceanography, 51(2): 830-837.

OKSANEN, J., F. G. BLANCHET, R. KINDT, P. LEGENDRE, P. R. MINCHIN, R. B. O'HARA, G. L. SIMPSON, P. SOLYMOS, M. H. H. STEVENS \& H. WAGNER. 2015. vegan: Community Ecology Package. R package version 2.3-0. URL http://CRAN.R-project.org/package=vegan

PÉREZ-MARTÍNEZ, C., J. BAREA-ARCO \& P. SÁNCHEZ-CASTILLO. 2001. Dispersal and colonization of the epibiont alga Korshikoviella gracilipes (Chlorophyceae) on Daphnia pulicaria (Cladocera). Journal of Phycology, 37: 724-730.

PÉREZ-MARTÍNEZ, C., J. BAREA-ARCO, J. M. CONDE-PORCUNA \& R. MORALES-BAQUERO. 2007. Reproduction strategies of Daphnia pulicaria population in a high mountain lake of Southern Spain. Hydrobiologia, 594: 75-82.

PÉREZ-MARTÍNEZ, C., L. JIMÉNEZ, J. M. CONDE-PORCUNA, E. MORENO, E. RAMOS-RODRÍGUEZ, O. HEIRI, G. JIMÉNEZ-MORENO \& S. R. ANDERSON. 2012. Efectos del cambio climático en los ecosistemas acuáticos y terrestres de alta montaña de Sierra Nevada: Análisis del registro fósil en los sedimentos. In: Proyectos de investigación en Parques Nacionales: 2008-2011. L. Ramírez \& B. Asensio (eds): 71-93. Organismo Autónomo de Parques Nacionales, Madrid, España. PÉREZ-MARTÍNEZ, C., L. JIMÉNEZ, E. MORENO \& J. M. CONDE-PORCUNA. 2013. Emergence pattern and hatching cues of Daphnia pulicaria (Crustacea, Cladocera) in an alpine lake. Hydrobiologia, 707: 47-57.
REUSS, N., P. R. LEAVITT, R. I. HALL, C. BIGLER \& D. HAMMARLUND. 2010. Development and application of sedimentary pigments for assessing effects of climatic and environmental changes on subarctic lakes in northern Sweden. Journal of $\mathrm{Pa}$ leolimnology, 43: 149-169.

REYNOLDS, C. S. 2006. The ecology of phytoplankton. Cambridge University Press. Cambridge. UK.

REYNOLDS, C. S., V. L. M. HUSZAR, C. KRUK, L. NASELLI-FLORES \& S. MELO. 2002. Towards a functional classification of the freshwater phytoplankton. Journal of Plankton Research, 24(5): 417-428.

RIGOSI, A., C. C. CAREY, B. W. IBELINGS \& J. D. BROOKES. 2014. The interaction between climate warming and eutrophication to promote cyanobacteria is dependent on trophic state and varies among taxa. Limnology and Oceanography, 59(1): 99-114.

ROMERO-VIANA, L., B. J. KEELY, A. CAMACHO, E. VICENTE \& M. R. MIRACLE. 2009. Photoautotrophic community changes in Lagunillo del Tejo (Spain) in response to lake level fluctuation: Two centuries of sedimentary pigment records. $\mathrm{Or}$ ganic Geochemistry, 40: 376-386.

ROMERO-VIANA, L., B. J. KEELY, A. CAMACHO, E. VICENTE \& M. R. MIRACLE. 2010. Primary production in Lake La Cruz (Spain) over the last four centuries: reconstruction based on sedimentary signal of photosynthetic pigments. Journal of Paleolimnology, 43: 771-786.

RÜHLAND, K., N. R. PHADTARE, R. K. PANT, S. J. SANGODE \& J. P. SMOL. 2006. Accelerated melting of Himalayan snow and ice triggers pronounced changes in a valley peatland from northern India. Geophysical Research Letters, 33(15): L15709.

RÜHLAND, K. M., A. M. PATERSON, W. KELLER, N. MICHELUTTI \& J. P. SMOL. 2013. Global warming triggers the loss of a key Arctic refugium. Proceedings of the Royal Society B: Biological Sciences, 280: 20131887.

SÁNCHEZ-CASTILLO, P. M. 1988. Algas de las lagunas de alta montaña de Sierra Nevada (Granada, España). Acta Botánica Malacitana, 13: 21-52.

SANGER, J. E. 1988. Fossil pigments in paleoecology and paleolimnology. Palaeogeography, Palaeoclimatology, Palaeoecology, 62: 343-359.

SCHLESINGER, D. A., L. A. MOLOT \& B. J. SHUTER. 1981. Specific growth rates of fresh- 
water algae in relation to cell size and light intensity. Canadian Journal of Fisheries and Aquatic Science, 38: 1052-1058.

SMOL, J. P. 2008. Pollution of Lakes and Rivers: a Paleoenvironmental Perspective. 2nd edition. Wiley-Blackwell publishing. Oxford. UK.

SMOL, J. P. 2010. The power of the past: using sediments to track the effects of multiple stressors on lake ecosystems. Freshwater Biology, 55 (Suppl. 1): 43-59.

SMOL, J. P., A. P. WOLFE, H. J. B. BIRKS, M. S. V. DOUGLAS, V. J. JONES, A. KORHOLA, R. PIENITZ, K. RÜHLAND, S. SORVARI, D. ANTONIADES, S. J. BROOKS, M-A. FALLU, M. HUGHES, B. E. KEATLEY, T. E. LAING, N. MICHELUTTI, L. NAZAROVA, M. NYMAN, A. M. PATERSON, B. PERREN, R. QUINLAN, M. RAUTIO, E. SAULNIER-TALBOT, S. SIITONEN, N. SOLOVIEVA \& J. WECKSTRÖM. 2005. Climate-driven regime shifts in the biological communities of arctic lakes. Proceedings of the National Academy of Sciences of the United States of America, 102(12): 4397-4402.

SOMMARUGA-WÖGRATH, S., K. A. KOINIG, R. SCHMIDT, R. SOMMARUGA, R. TESSADRI \& R. PSENNER. 1997. Temperature effects on the acidity of remote alpine lakes. Nature, 387: 64-67.

SORVARI, S. \& A. KORHOLA. 1998. Recent diatom assemblage changes in subarctic Lake Saanajärvi, NW Finnish Lapland, and their paleoenvironmen- tal implications. Journal of Paleolimnology, 20: 205-215.

STAUDT, M., M. J. ESTEBAN-PARRA \& Y. CASTRO-DÍEZ. 2007. Homogenization of long-term monthly Spanish temperature data. International Journal of Climatology, 27: 1809-1823.

SZERONCZYŃSKA, K. \& K. SARMAJA-KORJONEN. 2007. Atlas of Subfossil Cladocera from Central and Northern Europe. Friends of the Lower Vistula Society. Świecie.

TORO, M., \& I. GRANADOS. 2002. Restoration of a small high mountain lake after recent tourist impact: the importance of limnological monitoring and palaeolimnology. Water, Air and Soil Pollution: Focus, 2: 295-310.

TORO, M., I. GRANADOS, S. ROBLES \& C. MONTES. 2006. High mountain lakes of the Central Range (Iberian Peninsula): Regional limnology \& environmental changes. Limnetica, 25(1-2): 217252.

VERLEYEN, E., D. A. HODGSON, K. SABBE \& W. VYVERMAN. 2005. Late Holocene changes in ultraviolet radiation penetration recorded in an East Antarctic lake. Journal of Paleolimnology, 34: 191-202.

WOLFE, A. P., J. S. BARON \& R. J. CORNETT. 2001. Anthropogenic nitrogen deposition induces rapid ecological changes in alpine lakes of the Colorado Front Range (USA). Journal of Paleolimnology, 25: 1-7. 